\title{
Students' Perceptions towards Online Education during COVID-19 Pandemic: An Empirical Study
}

\author{
Sami Hussein Hakeem Barzani ${ }^{1} \&$ Rayan Jalal Jamil ${ }^{2}$ \\ ${ }^{1}$ English Language Teaching Department, Faculty of Education, Tishk International University, Iraq \\ ${ }^{2}$ Independent Researcher, Erbil, Iraq \\ Correspondence: Sami Hussein Hakeem Barzani, Tishk International University, Iraq \\ Email: Sami.hussein@tiu.edu.iq
}

Doi: $10.23918 /$ ijsses.v8i2p28

\begin{abstract}
The outbreak of COVID-19 has had a critical impact on the educational system around the world. Unwillingly, all educational institutions transited to online teaching. This study endeavoured to address the perceptions of Kurdish EFL university students of online education compared to on-campus education in terms of domains of preference, effectiveness, learning satisfaction, and challenges. To do so, data were collected quantitively as well as qualitatively. A sample of 200 university Kurdish EFL university students (112 female \& 88 male) from private and public universities of the Iraqi Kurdistan Region-Erbil participated. The results showed that the overwhelming majority of the students have a negative attitude toward online education. Similarly, they preferred and considered on-campus education more effective. The findings also revealed that the overwhelming majority of the students stated online education do not suffice their learning satisfaction. Finally, the challenges articulated by the students during online education included external factors, such as unstable internet connection, electricity besides internal ones, like time management, concentration difficulties, and opening cameras due to social issues.
\end{abstract}

Keywords: Online Education, COVID-19, On-Campus Education, Students' Perceptions

\section{Introduction}

The Pandemic of the novel Covid-19 infection has declared on $11^{\text {th }}$ March 2020 by the World Health Organization, and it has become a detrimental public health challenge globally (World Health Organization, 2020). Merriam-Webster Dictionary (2020) defines a pandemic as "an outbreak of a disease that occurs over a wide geographic area and affects an exceptionally high proportion of the population." The Covid-19 Pandemic critically affected all facets of life; the education sector is not exceptional. This is widely regarded as the worst public health disaster of the century and the greatest threat that humans have faced since World War II (Chakraborty, \& Maity, 2020). Medical tests soon confirmed the swift transfer of the virus from person to person and then from a country to another (Paules et al., 2020). To react against the spread of the virus, strict preventative measurements have been taken, from lockdowns, compulsory social distancing, travel bans, closure of sports activities, the shutdown of business, to the suspension of in-person education.

Received: April 24, 2021

Accepted: May 31, 2021

Barzani, S.H.H., \& Rayan Jalal Jamil, R.J. (2021). Students' Perceptions towards Online Education during COVID-19 Pandemic: An Empirical Study. International Journal of Social Sciences \& Educational Studies, 8(2), 28-38. 
To save education and continue the academic year, educational institutions worldwide shifted all their academic programs online. To a great extent, they were not fully ready for such an abrupt transition from in-person education to a complete virtual education. As Zhang, Wang, Yang, \& Wang (2020) stated, many of them lacked a robust technology infrastructure as well as wise strategies.

In the past few decades, there have been numerous developments in educational technologies, which have confirmed to be very helpful during this challenging time of Covid-19 (Chatterjee \& Chakraborty, 2020; Dhawan, 2020). This is in addition to the invention of various useful platforms to promote online education (Nash, 2020). On the other hand, educational institutions found it difficult to chart their instructive practices in an online environment. Instructors and students have had to deal with a variety of logistical, scientific, economic, and social issues (Lassoued, Alhendawi, \& Bashitialshaaer, 2020; Peters et al., 2020).

Notwithstanding its perilous effects, Covid-19 taught us many important lessons for various spheres of life, specifically in building a more substantial infrastructure of educational technology to use when facing any future similar catastrophes. In this line, research uncovering students' feedback may offer valuable data for improving possible learning strategies and a better road map in distance education. This will also assist policymakers in developing interventions and strategies to resolve the crisis's repercussions. Evidently, the results may help teachers and parents figure out how to serve students during this crisis better. Therefore, the present study intends to address the following research questions:

1. What are the preferences and attitudes of Kurdish EFL University Students towards online education during the Pandemic?

2. What are the most common challenges students face during online education imposed by Covid-19?

3. Does online education suffice students' needs?

\section{Literature Review}

Electronic transformation is not a recent phenomenon. Like its usage in any other areas, higher education institutions are now implementing it for several years (Kopp et al., 2019; Leszczyński et al., 2018). However, since this might not have been used globally everywhere as well as by all institutions, it might be considered a novel invention to some. Then, recently due to the outbreak of the Covid-19 Pandemic, which imposed an almost worldwide closure, this idea of digital transformation became more apparent. The impact of the Pandemic has been devastating to all aspects of life; however, since education is the most delicate sector, it has been badly affected. This is specifically true to the developing countries where not having enough experience and tools to face the issue. In nearly 188 countries across the globe, almost 900 million learners have been influenced by school and university shutdown (Nicola et al., 2020, p. 187). Additionally, As reported by Audrey Azoulay, UNESCO Director-General, "the global speediness and scope of the current educational distraction is incomparable and, if continued, could threaten the right to education" (UNESCO Press Release, 3 March 2020).

Though many efforts were made, and varying options experienced to save, contain, or at least lessen the negative impact on education, research has found many barriers and problems that are inevitable, anyway. Decreased time spent on learning, stress or depression, a transition in the way students communicate, and loss of enthusiasm for learning are the most visible detrimental effects that may result in distance education 
(Di Pietro et al., 2020). Likewise, Yoo et al. (2012) classify the serious issues of implementing e-learning successfully into three zones. First, human factors include attitudes of the user, styles of learning, and teacher's attitudes and teaching styles. Second, the factors of content and learning consist of the format of content delivered, structure, and authoring tools. Third, the institutional factors involve administrative policy, environment, or culture. Asides, as (Al Kurdi et al., 2020) indicates, lack of digital tools, computer literacy, electricity, and access to a proper internet connection are other issues that are more critical barriers to the success of different alternatives of physical education.

Soon after the outbreak of the Pandemic Covid-19, a massive body of research in relation to its impact on education undergone. Students' perceptions and attitudes towards online learning and their challenges have been investigated and focused visibly. This due to the significance of the issue that highly correlates to the success of the learning and teaching process. Several studies unveiled that most of the students are satisfied with online education. Learners' attitudes to educational technology strictly impact their learning process (Ali, 2020). In this line, Garcia Botero et al. (2008) investigated the aspects which impact behavioural intentions and the implementation of mobile-assisted language learning. The results showed that students' attitude suggestively affects their will to use mobile technology for language learning.

Muhammad and Kainat (2020) explored the attitudes of Pakistani students about online learning imposed by the COVID-19 Pandemic. The findings displayed that online learning cannot achieve desirable outcomes in developing countries like Pakistan. Likewise, Yunita and Maisarah (2020) explored the students' perception of the University of Bengkulu on the implementation of the learning process in time of covid-19 Pandemic. The findings exposed that the students had a positive perception of the application of online learning.

Despite some research supporting online education in terms of students' attitudes, the vast body of research figures out students show support to the class education over online one. Aguilera-Hermida (2020), in a survey conducted online to determine college students' beliefs and opinions towards the adoption, use, and acceptance of emergency online learning, revealed participants favoured physical learning to online learning. Similarly, the majority of students to the Chakraborty (2020) study responded they better learn physically attending classrooms than virtual education. Moreover, Amir et al. (2020) conducted a survey to figure out the Indonesian students' perspective on classroom learning and distance learning. The results unveiled although distance-learning might provide them more models of studying as well as more time for review, yet they do prefer class learning as it is more effective. External factors, namely poor internet connection, further financial load for the internet quota and internal factors as time organization and struggle to focus while learning online for a longer period, were named by the participants.

Furthermore, Nugroho et al. (2020) discovered that the overwhelming majority (80\%) of respondents showed negative attitudes to the online lecture mode due to the difficulties they faced and experienced. Additionally, Kalanit and Veronika (2020) explored the perceptions and challenges of students during online learning. The results illustrated that student have both technical and cognitive challenges. Thus, they showed negative attitudes toward online learning. Finally, Blizak, Blizak, Bouchenak, and Yahiaoui (2020) studied the perception of 380 Algerian university students to online Results, indicating that students hold a negative perception of online education they are hesitant about digital education and prefer in-class learning. 


\section{The Most Implemented Three Models of Education After Covid-19 Pandemic}

Following the disperse of Covid-19 globally, to continue as well as to save the academic year, the sole remedy at hand universities, schools, and colleges could consult was online education. However, teachers, students, and even the infrastructure of many educational institutions were not ready for this sudden and unexpected change (Keshavarz, 2020). Then, enormous ways were endeavored to turn education back on its proper path. The adoption of any model required technology. Technologies could back virtual-teaching and would be of great significance in education; however, it would not fully replace and achieve the results of face-to-face teaching. As Keshavarz (2020) furthers, teaching virtually may not suffices the needs of all types of learners.

\subsection{Online Learning}

The speedy advances in technology have ended up in the ease of virtual education (McBrien et al., 2009). These rapid developments have created various rooms for learning. Most of the terms, namely online learning, web-based learning, open learning, computer-mediated learning, and blended learning, refers to the almost exact model of teaching, which is to use a computer connected to a network, which enables us to learn from anywhere, anytime, in any rhythm, with any means (Cojocariu et al., 2014). According to Wang, Shannon, \& Ross (2013), Wilde \& Hsu (2019), distant or online education suggests that learners are apparently/physically remote from the teachers and claim a transference type/method. Keshavarz (2020, p. 1386) stated: "traditional teaching strategies are practical; however, with advances in educational technology, the effectiveness of traditional learning methods has become something of the past." Despite the usefulness of such a model of teaching and learning, there are many problems associated with it. These difficulties range from connection issues, transferring errors, login problems, difficulties with video and audio, and so on. Personal attention and student engagement are two critical matters facing online learning. A two-way interaction usually appeals to students more, which via online teaching this gets difficult to implement fully. The learning is not potentially achieved unless what is taught is practiced by the students, and usually, the content delivered online is more theoretical and does not allow the chance of practice. In this line, Song et al. (2004) further the dearth of community, technical difficulties, and problems associated with understanding directives are the chief obstacles for online learning.

\subsection{E-Learning}

Earlier to the outbreak of pandemic Covid-19, which forced the world to shift to electronic teaching and learning options, as Mahajan (2018) stated, E-learning has never been so embraced and accepted as an authentic learning or the formal model of education. Hall (2003) defined E-learning as the mode in which instructions and the teaching materials are distributed electronically through the Internet, multi-media channels such as DVD, CD-ROM, or digital television. As Keshavarz (2020) stated, students are accountable for those materials needed to prepare for any assessment requirements of the course. However, E-learning offers numerous opportunities and incentives to the partakers; they must be well-adjusted to the difficulties encountered in its deployment and management in different contexts (Al-Harbi, 2011; Qureshi et al., 2012). This form of education there is no Since students and teachers do not meet face-toface through this form of education so they can only speak and engage with one another electronically and through the medium of writing. Though through this method, matters of distance and time are no longer 
barriers to education, yet a sense of learner isolation, absence of immediate feedback, learner frustration, anxiety, confusion, self-motivation, a strong sense of commitment to online learning, engagement, and difficulties in communication between the students and teachers are among the prominent challenges.

\subsection{Blended Learning}

Blended learning is considered the combination of classroom and online learning to allow students to learn independently, interactively, and collaboratively. However, to put it in a broader context, blended learning restructures courses that are designed, planned, and executed using a hybrid of online and offline learning experiences. In this line, Keshavarz (2020) points out that the chief difference of this method to other forms of virtual education is the combination of both traditional on-campus teaching and online teaching. Previous research has indicated that blended learning, compared to other models of virtual education, offers better students' interest, enthusiasm, commitment, and success (Soltanimehr et al., 2019; Donkin et al., 2019; Schlenz et al., 2020; \& Wang, R. \& Liu, C. 2019). This method develops active and autonomous learning and has embraced various educational contexts as a supplementary method to traditional education.

\section{Methodology}

This study attempted to uncover the attitudes and preferences of Kurdish University Students regarding the online education which forced during the pandemic covid-19. To do so, the most appropriate method was a mixed research design, including quantitative and qualitative methods. Such research design intends to uncover how individuals think, perform, or feel in a certain way and find in-depth responses. Therefore, the implementation of such a research design helped the researcher address a larger number of participants and better address the objectives and research questions of the study.

\subsection{Participant and Setting}

The present study comprised of 200 (88 male \& 112 female) Kurdish EFL University Students. The participants were from different universities, including private as well as public ones, in Erbil, Iraqi Kurdistan Region, ranging from freshmen to seniors. A convenience sampling was used to address the participants. That is, they were chosen based upon their willingness of participation. The study was conducted during the academic years 2020-2021. Table 1 below presents a picture of the participants.

Table 1: Kurdish EFL University Students' Statistics

\begin{tabular}{|c|c|c|c|c|c|c|c|c|}
\hline \multirow[t]{2}{*}{ No. } & \multirow[t]{2}{*}{ University type } & \multicolumn{4}{|c|}{ Stage } & \multicolumn{2}{|c|}{ Gender } & \multirow[t]{2}{*}{ Number } \\
\hline & & $1^{\text {st }}$ & $2^{\text {nd }}$ & $3^{\text {rd }}$ & $4^{\text {th }}$ & Male & Female & \\
\hline 1 & State & 13 & 29 & 34 & 39 & 47 & 68 & 115 \\
\hline 2 & Private & 9 & 21 & 18 & 37 & 41 & 44 & 85 \\
\hline Total & & 22 & 50 & 52 & 76 & 88 & 112 & 200 \\
\hline
\end{tabular}




\subsection{Data Collection Instruments and Data Analysis}

For the present study, data were collected using a 15 items Likert-scale questionnaire in addition to one open-ended question (see appendix 1). The researchers devised the questionnaire to determine the attitudes of Kurdish EFL students concerning online and on-campus teaching. The questionnaire included two parts. Part one dealt with demographic information, and part two related to the attitudes and perceptions of the students, which touched upon four domains (attitude domain, effectiveness domain, learning satisfaction domain, and challenge domain). The collected data were numeric; therefore, they were analyzed using SPSS.

\section{Results}

For the gatherings of this survey data, the questionnaire was delivered arbitrarily to the learners through an online form. The questionnaire survey contained four domains; each domain had different questions; the first session of the domain is called Perception of Attitude Domain it includes four other questions, the second session of the domain is called Effectiveness Domain it also contains six questions, the third session of the domain is Learning Satisfaction Domain it involves five various questions. The fourth and last domain is called Challenge Domain, and this well contains eight questions, with the responses of (Strongly Disagree, Disagree, Neutral, Agree, Strongly Agree).

\subsection{Perception of Attitude Domain}

The first domain (4 items) in the questionnaire addressed the students' perception of attitudes and preferences towards online education to that of physical one. As Table 2 below depicts, a strong majority of the students $71.5 \%$ (S. Disagree \& Disagree) hold a negative attitude towards online education. To further clarify this, students' responses to item 4 (I am happier with on-campus learning than online learning) uncovered that the overwhelming majority, 84.8\% (Agree \& S. Agree), prefer on-campus education. Similarly, $81.2 \%$ of the respondents prefer not to continue the next semester virtually, which this also supports the negative attitudes of Kurdish EFL university students about virtual education.

Table 2: Perception of Attitude Domain

\begin{tabular}{|l|l|l|c|l|l|l|l|}
\hline Items & $\begin{array}{l}\mathrm{SD} \\
(1)\end{array}$ & $\begin{array}{c}\mathrm{D}(2) \\
\%\end{array}$ & $\begin{array}{c}\text { Total } \\
(1+2) \\
\%\end{array}$ & $\begin{array}{c}\mathrm{N}(3) \\
\%\end{array}$ & $\begin{array}{l}\mathrm{A}(4) \\
\%\end{array}$ & $\begin{array}{l}\text { sA (5) } \\
\%\end{array}$ & $\begin{array}{l}\text { Total } \\
(4+5) \\
\%\end{array}$ \\
\hline $\begin{array}{l}\text { 1. On the overall, I feel good about online } \\
\text { education }\end{array}$ & 46.6 & 24.9 & 71.5 & 4.3 & 14.3 & 9.9 & 24.2 \\
\hline $\begin{array}{l}\text { 2. I do enjoy learning online } \\
\text { 3. I want to continue online education for } \\
\text { the next semester }\end{array}$ & 60.6 & 20.6 & 81.2 & 3.6 & 8.8 & 6.4 & 15.2 \\
\hline $\begin{array}{l}\text { 4. I am happier with on-campus learning } \\
\text { than online learning }\end{array}$ & 3.3 & 6.9 & 10.2 & 5 & 25.9 & 58.9 & 84.8 \\
\hline
\end{tabular}




\subsection{Perception of Effectiveness Domain}

Regarding the effectiveness of the online education imposed by the Pandemic, a remarkable majority of the participants, 76\% (S. Disagree \& Disagree), stated a negative perception. 80.5\% (Agree \& S. Agree) of the respondents stated face-to-face learning is more effective than online learning. Similarly, concerning assessment, $71.7 \%$ of the students were of the idea that assessment is not effectively carried out in virtual learning. In the same line, $61.7 \%$ of the students stated online education is more stressful than traditional education. Finally, the results also indicated that students find the classroom more helpful and effective in receiving feedback.

Table 3: Perception Effectiveness Domain

\begin{tabular}{|l|c|c|c|c|c|c|c|}
\hline \multicolumn{1}{|c|}{ Items } & $\begin{array}{c}\mathrm{SD} \\
(1) \\
\%\end{array}$ & $\begin{array}{c}\mathrm{D}(2) \\
\%\end{array}$ & $\begin{array}{c}\text { Total } \\
(1+2) \\
\%\end{array}$ & $\begin{array}{c}(3) \\
\%\end{array}$ & $\begin{array}{c}\text { A (4) } \\
\%\end{array}$ & $\begin{array}{c}\text { SA (5) } \\
\%\end{array}$ & $\begin{array}{c}\text { Total } \\
\text { (4+5) \% }\end{array}$ \\
\hline 1. Online learning is effective & 50.2 & 25.5 & 76 & 5.9 & 14.2 & 4.2 & 18.4 \\
\hline $\begin{array}{l}\text { 2. Learning is the same in class and at } \\
\text { home on the Internet }\end{array}$ & 47 & 33.5 & 80.5 & 8.4 & 6.2 & 4.9 & 11.1 \\
\hline $\begin{array}{l}\text { 3. Assessment is more suitable } \\
\text { delivered in online learning }\end{array}$ & 41.9 & 29.8 & 71.7 & 6.1 & 10.4 & 11.8 & 22.2 \\
\hline $\begin{array}{l}\text { 4.I can better manage my time with } \\
\text { online learning }\end{array}$ & 32.4 & 20.6 & 53 & 18.8 & 19.3 & 8.9 & 28.2 \\
\hline $\begin{array}{l}\text { 5. Online learning is less stressful than } \\
\text { in-class learning }\end{array}$ & 39.8 & 21.9 & 61.7 & 13.4 & 15.9 & 9 & 24.9 \\
\hline $\begin{array}{l}\text { 6. I can ask my teacher questions and } \\
\text { receive a quick response during online } \\
\text { activities }\end{array}$ & 30.7 & 15.3 & 46 & 15.7 & 25.9 & 12.4 & 38.3 \\
\hline
\end{tabular}

\subsection{Learning Satisfaction Domain}

The third domain in the questionnaire (5 items) was devoted to exploring students' perceptions about learning satisfaction online. As Table 4 pictures, to a great extent, all the five items show that students are not happy with online education as well as it does not satisfy their learning fulfilment. A substantial majority of the participants, 78,7\% (S. Disagree \& Disagree), were of the idea that online education does not satisfy their learning as on-campus education. $72.7 \%$ (S. Disagree \& Disagree) stated that collaboration with peers is not easy virtually. Similarly, a remarkable majority of the respondents, $71.2 \%$ (S. Disagree \& Disagree), oppose the idea that they study more efficiently with online education. Finally, however, some believe that online education leads to self-directed learning; results of the present study show an opposite idea; $60.3 \%$ of the respondents stated against this belief. 
Table 4: Perception of Learning Satisfaction Domain

\begin{tabular}{|l|c|c|c|c|c|c|c|}
\hline \multicolumn{1}{|c|}{ Items } & $\begin{array}{c}\mathrm{SD}(1) \\
\%\end{array}$ & $\begin{array}{c}\mathrm{D}(2) \\
\%\end{array}$ & $\begin{array}{c}\text { Total } \\
1+2) \%\end{array}$ & $\begin{array}{c}\mathrm{N}(3) \\
\%\end{array}$ & $\begin{array}{c}\mathrm{A}(4) \\
\%\end{array}$ & $\begin{array}{c}\text { SA (5) } \\
\%\end{array}$ & $\begin{array}{c}\text { Total } \\
4+5) \%\end{array}$ \\
\hline $\begin{array}{l}\text { 1. Online learning gives similar learning } \\
\text { satisfaction as classroom learning }\end{array}$ & 49.3 & 29.4 & 78.7 & 11.8 & 5.7 & 3.8 & 9.5 \\
\hline $\begin{array}{l}\text { 2. Communicating with my classmates } \\
\text { and instructors is easier electronically }\end{array}$ & 34.6 & 20 & 54.6 & 10.2 & 20.3 & 14.9 & 35.2 \\
\hline $\begin{array}{l}\text { 3. I can better collaborate with other } \\
\text { students during online activities }\end{array}$ & 51.1 & 21.6 & 72.7 & 11 & 9.4 & 5.9 & 15.3 \\
\hline $\begin{array}{l}\text { 4. I study more efficiently with online } \\
\text { learning }\end{array}$ & 40.7 & 30.5 & 71.2 & 14.6 & 7.4 & 6.9 & 14.3 \\
\hline $\begin{array}{l}\text { 5.Online education leads to self-directed } \\
\text { learning, which I prefer it }\end{array}$ & 38.2 & 22.1 & 60.3 & 15.1 & 18.7 & 5.9 & 24.6 \\
\hline
\end{tabular}

\subsection{Challenge Domain}

As to address the challenge domain, students were asked to respond to an open-ended question (Mention any challenges and difficulties you faced during online education). The responses were categorized, and the percentage was taken. As Table 5 below illustrates, the challenges and difficulties students faced include external factors as well as internal ones. Only a small number of the $19.5 \%$ did not experience difficulties during online education. Problems of unstable internet connection $76 \%$ and the lack of required computer skills $72 \%$ stated to be the most critical difficulties of a substantial majority of the students. Additionally, electricity $60.5 \%$ was another visible difficulty of the participants, which is not surprising in our context. Moreover, lack of knowledge of the tools and apps used for online education 49\%, opening cameras during online lessons $45.5 \%$, access to a proper device $44.5 \%$, concentration problems $42 \%$, and extra financial problems $39 \%$ were the challenges and obstacles of the respondents.

Table 5: Perception of Challenge Domain

\begin{tabular}{|l|c|c|}
\hline Items & No. & Percentage \\
\hline 1. No problems experienced during online learning & 39 & $19.5 \%$ \\
\hline $\begin{array}{l}\text { 2. No access to a sufficient internet connection for online } \\
\text { learning }\end{array}$ & 152 & $76 \%$ \\
\hline $\begin{array}{l}\text { 3. Not having the necessary computer skills for doing online } \\
\text { learning }\end{array}$ & 145 & $72.5 \%$ \\
\hline 4. Having electricity problems for online learning & 121 & $60.5 \%$ \\
\hline $\begin{array}{l}\text { 5. Having difficulties with the tools and online platforms } \\
\text { being used by my university }\end{array}$ & 98 & $49 \%$ \\
\hline 6. Opening cameras due to social issues & 91 & $45.5 \%$ \\
\hline 7. Access to a proper device & 89 & $44.5 \%$ \\
\hline 8. Concentration problems & 84 & $42 \%$ \\
\hline 9. Extra financial problems & 78 & $39 \%$ \\
\hline
\end{tabular}




\section{Conclusions}

Online education is not a novel channel for teaching and learning. It has been in use for a long time, either partially by some or entirely by some other academic institutions. However, the Covid-19 Pandemic forced all educational institutions to resort to. The abrupt transition from on-campus education to virtual one not only was an easy step, despite its aids, but it also resulted in many difficulties. The present study aimed at addressing this issue from the perspectives of the learners. This is due to the fact that learners are the ones affected the most. The study focused on various domains, namely Attitude Domain, Effectiveness Domain, Learning Satisfaction Domain, and Challenge Domain. The findings indicated that a strong majority of the respondents have a negative attitude towards online education. Likewise, the respondents favoured and considered on-campus education more effective. The results also exposed that the overwhelming majority of the students stated online education do not suffice their learning satisfaction. Finally, respondents stated during online education; they faced various challenges and difficulties. These challenges included external factors, such as unstable internet connection, electricity besides internal ones, like time management, concentration difficulties, and opening cameras due to social issues.

The study hopes, based on the findings, to result in prolific pedagogical implications.

\section{References}

Aguilera-Hermida, A. P. (2020). College students' use and acceptance of emergency online learning due to COVID-19. International Journal of Educational Research Open. https://doi.org/10.1016/j.ijedro.2020.100011

Al Kurdi, B., Alshurideh, M., \& Salloum, S.A. (2020). Investigating a theoretical framework for elearning technology acceptance. Int. J. Electr. Comput. Eng., 10, (6), 6484-6496. http://doi.org/10.11591/ijece.v10i6.pp6484-6496

Altun, M., \& Sabah, R. (2020). The Effect of Cooperative Learning Strategies in the Enhancement of EFL Learners' Speaking Skills. Asian EFL Journal, 27(2), 144-171.

Altun, M. (2015). The integration of technology into foreign language teaching. International Journal on New Trends in Education and Their Implications, 6(1), 22-27.

Altun, M. (2019). An underestimated tool: Body language in classroom during teaching and learning. International Journal of Social Sciences \& Educational Studies, 6(1), 155-170.

Amir, L. R., Tanti, I., Maharani, D. A., Wimardhani, Y. S., Julia, V., Sulijaya, B., \& Puspitawati, R. (2020). Student perspective of classroom and distance learning during COVID-19 Pandemic in the undergraduate dental study program Universitas Indonesia. BMC Medical Education, 20(1), 1-8. https://doi.org/10.1186/s12909-020-02312-0

Barzani, S. H. H. (2020). The perceptions of EFL teachers and students on the use of short stories to enhance reading comprehension. Asian EFL Journal, 27(3.1), 325-341.

Barzani, S. H. H. \& Nabee, N. S. (2020). Kurdish efl students' attitudes and preferences toward extensive reading. PalArch's Journal of Archaeology of Egypt/Egyptology, 17(7), 8192 8207.

Black, D., Blizak, S., Bouchenak, Q., \& Yahiaoui, K. (2020). Students' perceptions regarding the abrupt transition to online learning during the COVID-19 Pandemic: Case of Faculty of Chemistry and Hydrocarbons at the University of boumerdes-Algeria. Journal of Chemical Education, 97(9), 2466-2471. DOI: 10.1021/acs.jchemed.oc00668 
Cojocariu, V.-M., Lazar, I., Nedeff, V., \& Lazar, G. (2014). SWOT analysis of e-learning educational services from the perspective of their beneficiaries. Procedia-Social and Behavioral Sciences, 116, 1999-2003.

Chakraborty, P, Mittal, P, Gupta, MS, Yadav, S, \& Arora, A. (2020). Opinion of students on online education during the COVID-19 Pandemic. Human Behavior \& Emerging Technologies 1-9. https://doi.org/10.1002/hbe2.240

Chakraborty, I., \& Maity, P. (2020). COVID-19 outbreak: Migration, effects on society, global environment and prevention. Sci Total Environ. 728, 138882. doi:10.1016/j.scitotenv.2020.138882

Chatterjee, I., \& Chakraborty, P. (2020). Use of information and communication technology by medical educators amid COVID-19 Pandemic and beyond. Journal of Educational Technology Systems in the Press, 49(3), 310-324. https://doi.org/10.1177/0047239520966996

Donkin, R., Askew, E. \& Stevenson, H. (2019). Video feedback and e-Learning enhances laboratory skills and engagement in medical laboratory science students. BMC Med Educ 19, 310. https://doi.org/10.1186/s12909-019-1745-1

Dhawan, S. (2020). Online learning: A panacea in the time of the COVID-19 crisis. Journal of Educational Technology Systems, 49(1), 5-22.

Fuad, H. A. \& Ulker, V. (2020). The effect of inquiry-based approach on development of reading and writing skills of a university EFL students. Asian EFL Journal, 27(2.3), 84-100.

Kalanit, F., J., \& Veronika, S., A. (2020). Is online learning a win-win solution? The teachers and students' stories. Jurnal Pendidikan Profesi Guru. 1(2), 73-82. https://doi.org/10.22219/jppg.v1i2.13470

Keshavarz, M. (2020). A Proposed Model for Post-Pandemic Higher Education. Budapest International Research and Critics in Linguistics and Education (Birle) Journal, 3(3), 1384-1391. https://doi.org/10.33258/birle.v3i3.1193

Kopp, M., Gröblinger, O., \& Adams, S. (2019, March 11-13). Five common assumptions that prevent digital transformation at higher education institutions. INTED2019 Proceedings (pp. 14481457). https://doi.org/10.21125/inted.2019

Khan, M.A.; Vivek; Nabi, M.K.; Khojah, M.; Tahir, M. (2021) Students' Perception towards E-Learning during COVID-19 Pandemic in India: An Empirical Study. Sustainability, 57 (13). https://doi.org/10.3390/su13010057

Lassoued, Z., Alhendawi, M., \& Bashitialshaaer, R. (2020). An exploratory study of the obstacles for achieving quality in distance learning during the COVID-19 Pandemic. Education Sciences, 10(9), 232.

Leszczyński, P., Charuta, A., Łaziuk, B., Gałązkowski, R., Wejnarski, A., Roszak, M., \& Kołodziejczak, B. (2018). Multimedia and interactivity in distance learning of resuscitation guidelines: A randomised controlled trial. Interactive Learning Environments, 26, (2), 151-162. https://doi.org/10.1080/10494820.2017.1337035

Mahajan M V, Kalpana R. (2018). A study of students' perception about e-learning. Indian J Clin Anat Physiol 5(4), 501-507.

McBrien, J. L., Cheng, R., \& Jones, P. (2009). Virtual spaces: Employing a synchronous online classroom to facilitate student engagement in online learning. The International Review of Research in Open and Distributed Learning, 10(3), 1-17.

Muhammad A, Kainat A. (2020). Online learning amid the COVID-19 Pandemic.: Students' perspectives. Journal of Pedagogical Sociology and Psychology, 2(1): 45-51.

Nash, C. (2020). Report on digital literacy in academic meetings during the 2020 COVID-19 lockdown. Challenges, 11(2), 20. 
Peters, M. A., Wang, H., Ogunniran, M. O., Huang, Y., Green, B., Chunga, J. O., Khomera, S. W. (2020). China's internationalized higher education during COVID-19: Collective student autoethnography. Post-digital Science and Education, 2(3), 968-988

Song, L., Singleton, E. S., Hill, J. R., \& Koh, M. H. (2004). Improving online learning: Student perceptions of practical and challenging characteristics. The Internet and Higher Education, 7(1), 59-70.

Soltanimehr, E., Bahrampour, E., Imani, M.M. et al. (2019). Effect of virtual versus traditional education on theoretical knowledge and reporting skills of dental students in radiographic interpretation of bony lesions of the jaw. BMC Med Educ, 19(233), 1-7.

Schlenz, M.A., Michel, K., Wegner, K. et al. (2020). Undergraduate dental students' perspective on the implementation of digital dentistry in the preclinical curriculum: a questionnaire survey. $B M C$ Oral Health 20, 78. https://doi.org/10.1186/s12903-020-01071-0

Wang R, Liu C. (2019). The relation of dental students' learning styles to their satisfaction with traditional and inverted classroom models. BMC Med Educ. 19, 315. https://doi.org/10.1186/s12909-019-1749-x

World Health Organization. (2020). https://www.who.int/dg/speeches/detail/ who-director-general-sopening-remarks-at-the-media-briefing-on-covid-1 9\%2D\%2D-11-march-2020

Yoo, S.J., Huang, W-H, et al., (2012). The impact of employee's perception of organizational climate on their technology acceptance toward e-learning in South Korea, Knowledge Management \& ELearning. An International Journal, 4,(3), 359.

Zirak Haseeb Chicho, Kanar (2021) Embodied learning implementation in EFL classroom: A qualitative study. International Journal of Social Sciences \& Educational Studies, 8(1), 51-58. pp. 51-58. Doi: 10.23918/ijsses.v8i1p51

Zhang, W., Wang, Y., Yang, L., \& Wang, C. (2020). Suspending classes without stopping learning: China's education emergency management policy in the COVID-19 outbreak. Journal of Risk and Financial Management, 13(3), 55. 